IRSTI 06.51.87

\author{
Mukan M.M. ${ }^{1}$, Issabayev M.M. ${ }^{2}$ \\ ${ }^{1}$ Doctoral student, e-mail: moldir.mukan@narxoz.kz \\ ${ }^{2} \mathrm{PhD}$, Research - Professor, Applied Research Institute, e-mail: murat.isabayev@narxoz.kz \\ Narxoz Univeristy, Kazakhstan, Almaty

\section{THE RELATIONSHIP BETWEEN CREDITWORTHINESS AND STOCK MARKET DEVELOPMENT OF OIL-EXPORTING COUNTRIES}

\begin{abstract}
Today, the main source of economic growth is the extraction of mineral oil, although in recent years there has been a significant increase in the role of consumer demand in the domestic market. In the context of globalization, the main indicator of the economy of oil-producing countries is oil prices. However, in a period of globalization, developing countries need not only energy, but also economic resources to develop their economic situation on the global market. Thus, establishing creditworthiness is the key to attracting foreign capital. The development of the stock market is not an indicator of the country's stable creditworthiness. This study fills the required gap, verifying with the extent to which the development of the stock market can affect creditworthiness. Moreover, the following article has strong literature review in order to identify and summarize the main factors of the creditworthiness of oil-producing countries. Although, there is not strong empirical research, the study is based on the statistical world data.
\end{abstract}

Key words: creditworthiness, credit rating agency, oil-exporting countries, stock market

\author{
Мұқан M.M. ${ }^{1}$, Исабаев M.M. ${ }^{2}$ \\ ${ }^{1}$ Аокторант, e-mail: moldir.mukan@narxoz.kz \\ 2PhD, профессор-зерттеуші, \\ Қолданбалы зерттеулер институты, e-mail: murat.isabayev@narxoz.kz \\ Нархоз университеті, Қазақстан, Алматы қ. \\ Мұнай экспорттаушы елдердің қор нарығының \\ несиелік қабілеттікігі және дамуы
}

Бүгінде экономикалық өсудің негізгі көзі мұнай өнімдерін өндіру болып табылады, бірақ, соңғы жы^дары отандық нарықтағы тұтынушылық сұраныстың рөлі айтарлықтай өсті. Жаһандану жағдайында мұнай өндіруші елдердің экономикасының негізгі көрсеткіші мұнай бағалары болып табылады. Аегенмен, жаһандану кезеңінде дамушы елдер әлемдік нарықта олардың экономикалық жағдайын дамыту үшін тек энергетикаға ғана емес, сондай-ақ экономикалық, ресурстарға да мұқтаж. Осылайша, несие қабілеттілігін құру шетелдік капитал тартудың кілті болып табылады. Қор нарығының дамуы елдің тұрақты кредит қабілеттілігінің көрсеткіші болып табылмайды. Бұл зерттеу қор нарығының несиелік қабілеттілігіне әсер ету деңгейін растайтын қажетті бос орынды толтырады. Бұдан басқа, келесі мақаяада мұнай өндіруші елдердің негізгі несиелік факторларын анықтау және жинақтау үшін әдебиеттерді егжей-тегжейлі қарастырады. Күшті эмпирикалық зерттеулер болмаса да, зерттеу ғаламдық статистикалық, Аеректерге негізделген.

Түйін сөздер: кредиттік қабілеттілігі, кредиттік рейтинг агенттігі, мұнай экспорттаушы елдер, қор нарығы 


\author{
Мукан М.M. ${ }^{1}$, Исабаев M.M. ${ }^{2}$ \\ ${ }^{1}$ Аокторант, e-mail: moldir.mukan@narxoz.kz \\ ${ }^{2} \mathrm{PhD}$, профессор-исследователь, \\ Институт прикладных исследований, e-mail: murat.isabayev@narxoz.kz \\ Университет Нархоз, Казахстан, г. Алматы \\ Кредитоспособность и развитие фондового рынка \\ нефтеэкспортирующих стран
}

\begin{abstract}
На сегодняшний день основным источником экономического роста является добыча нефтепродуктов, хотя в последние годы значительно выросла роль потребительского спроса на внутреннем рынке. В условиях глобализации основным показателем экономики нефтедобывающих стран являются цены на нефть. ОАнако в период глобализации развивающиеся страны нужАаются не только в энергии, но и в экономических ресурсах А^я развития своей экономической ситуации на мировом рынке. Таким образом, установление кредитоспособности является кАючом к привлечению иностранного капитала. Развитие фондового рынка не является показателем стабильной кредитоспособности страны. Это исследование заполняет необходимый пробел, подтверждая степень, с которой развитие фондового рынка может повлиять на кредитоспособность. Кроме того, в следующей статье представлен подробный обзор литературы с целью выявления и обобщения основных факторов кредитоспособности нефтедобывающих стран. Хотя нет сильных эмпирических исследований, исследование основано на статистических мировых данных.
\end{abstract}

Кмючевые слова: кредитоспособность, агентство кредитных рейтингов, страны-экспортеры нефти, фондовый рынок.

\section{Introduction}

The creditworthiness is a comprehensive legal and financial characteristics of the borrower, represented by financial and non-financial indicators, which allows assessing its ability to pay the loan in full and on time in the future. Generally, the creditworthiness means if the borrower will be able to pay back the loan usually with the interest rate. In the modern world, countries also have the applicable term 'creditworthiness'. As companies, the countries are also rated on their creditworthiness. In this case, we also take country's creditworthiness as a kind of reliability indicator that reflects the borrower's ability to get a loan and return it on time. If the state's rating falls, the investment attractiveness of its market automatically decreases (www.countryeconomy.com).

Before deciding whether to invest in a debt security of a company or a foreign country, it is necessary to determine whether the intended issuing organization will be able to fulfill its obligations. Rating agencies can help to do this. By providing independent, objective credit ratings of companies and countries, rating agencies help investors decide how dangerous it will be to invest in a specific country and / or security.

\section{Literature Review}

The stock market is the object of study of many domestic and foreign authors. The work (Bernanke,
2016) shows that there is a strong and positive interaction between oil and the stock index. These variables both respond to the underlying changes in global demand. The premise is that commodity prices, long-term interest rates, and the dollar are likely to respond to investors' perceptions of global and American demand, rather than as much change in oil supply.

There are different works that research the creditworthiness of the country with various ways of its assessment. For example, Kharas (1984) analyzed the determinants of developing country long-run creditworthiness, focusing on the process of capital accumulation relative to external debt. In his work, creditworthiness depends on the fixed capital, and not on that critical point, when the capital is sufficient only to repay the interest on payments, thereby not depleting the national production volume. In this case, two factors are taken into account: the expected income from production and the existing outstanding debt.

Consequently, a country whose actual capital exceeds this minimum is creditworthy. Different shocks can either raise the critical capital stock above the actual level, or lower the latter below the first. Then the country ceases to be creditworthy and is forced to revise the schedule of work with its creditors.

In the work of Rowland (2004), there was investigated a panel-data framework to identify the determinants of the spread over US Treasuries of emerging market sovereign issues as well as 
of the creditworthiness of the issuers, where the latter is represented by the Institutional Investor's creditworthiness index. There is represented a sample of 16 emerging market economies, together with time series data for the period from 1987 to 2001 when analyzing the creditworthiness. The results suggest that for both the spread and the creditworthiness, significant explanatory variables include the economic growth rate, the debt-to-GDP ratio, the reserves-to-GDP ratio, and the debt-toexports ratio. In addition, the creditworthiness is influenced by the inflation rate and a default variable.

If we consider the credit agencies and how they assess countries' credit ratings, we can take in to account the work of Adeem Ul Haque et.al (1996). Certain criteria that rating agencies follow to assign a credit rating are discussed. Ratings are based on estimates of a number of macroeconomic, financial and political variables, including a country's economic growth rate, its current account balance in relation to GDP and various ratios - savings to investments, external debt to GDP, debt service payments in GDP and interest payments in GDP. In addition, the country's vulnerability is taken into account, if the country's economy is completely dependent only on one export. A country's willingness to service its financial obligations is measured by financial variables, such as international bank debt, debt restructuring, access to bond markets and the cost of various forms of trade credit, and political considerations, which usually include policies on foreign creditors, the government's ability to implement measures necessary to stabilize the economy and meet external payments. It was found that the most important domestic economic variables affecting a country's credit rating are the ratio of foreign exchange reserves to imports, the ratio of current account balance to GDP, the rate of growth of the country and the rate of inflation. The impact of inflation on credit ratings is nonlinear, since countries with high inflation face severe penalties compared to countries with low or moderate inflation. In addition, its regional location and types of exported goods often influence a country's credit rating. Although the conditions of the international financial market are rarely mentioned as factors affecting a country's credit rating, it was found that an increase in international interest rates would adversely affect the ratings of all developing countries, regardless of the quality of domestic economic indicators

As documented by Gelos et al. (2011), many lowincome countries do not have access to international bond markets, but it would be wrong to conclude that perceived creditworthiness is irrelevant in these cases: the likelihood of default may still affect the availability of bank loans, trade credit etc. The Institutional Investor (IICCR) ranks countries on a scale from 0 to 100 , with a lower rating reflecting a higher likelihood that borrowers in this country will default on their debt.

However, Harms and Rauber (2006) explored whether foreign aid affects developing countries' creditworthiness, as proxied by the Institutional Investor's measure of country credit risk. Based on a simple model of international borrowing and lending, there was developed the hypothesis that current aid reduces the likelihood of future default. Then, they tested the hypothesis, using a data set that covers a large number of developing countries in the 1980s and 1990s. While the size of the effect differs across types of aid and country groups, our empirical findings support the notion that aid improves countries' standing vis-a-vis international capital markets. Their aim is to test whether foreign aid actually has a positive effect on countries' creditworthiness, as measured by the country credit ratings published in the Institutional Investor (IICCR).

However, the conducted studies, which were described above did not reveal the behavior of the stock market under the pressure of oil price volatility, as well as the subsequent impact on the creditability of oil-producing countries.

\section{Methodology}

The article has two types of approaches. First, concerning the qualitative approach, the research is based on the works of previous foreign authors on this topic. A review of the most interesting hypotheses and research results of impact of the countries' creditworthiness on oil prices and stock markets revenue is proposed. The following type of the research gives us the insight of the issue.

Second, the quantitative approach is proposed by statistics and accumulated data.

These types of methodology have different ways of the research. In the same time, both types of approaches complement each other. So, qualitative approach gives us methodology and hypothesis, while quantitative prove this hypothesis from the statistical view. Quantitative method of the research is more structural and gives us the clear performance of the countries' financial side.

In this article, we use reliable sources of information as the World Bank and other highly recommended internet sources with all economic 
data. Moreover, the works of foreign authors are proposed as secondary source of data base.

\section{Results and Discussion}

This paper considers academic literature from research appeal. Opening such a popular and discussed topic as the interaction between oil prices, creditworthiness and the stock market, the main reasons for this relationship.

The stock market contributes to economic growth in various ways. First, without efficient capital markets, investors have limited means to diversify their portfolios and may avoid equity stakes because of risk. Hence, corporations may find it difficult to raise equity capital. Creation of stock markets allows individuals to diversify firmspecific risks, thus making investment in firms more attractive. In order to attract investment capital in countries with poorly functioning capital markets, corporations may choose lower value - low risk projects to inefficiently diversify. They serve the purpose of diversifying because the capital markets have not provided the means for investors within that country to efficiently diversify. Hence, the stock market may play a key role in economic growth.

As an example, we take some of the oil-exporting countries. These countries are Kazakhstan, Vietnam, Indonesia, Russia, Malaysia, UAE, Saudi Arabia (www.trademap.org). The focus on oil-producing countries is interesting for at least one reason: these countries provide with oil really strong countries, supporting the development of the world economy. The aim is to identify the causes of oil price volatility that influence on the stock market of oil-producing countries, as well as point out which impact it has on the creditworthiness of these countries (Bernanke, 2016).

The countries' creditworthiness is mainly assessed by credit agencies, which further give the credit ratings. The presence of a credit rating reveals the country's objective financial capabilities, enhances the reputation of the government as ready to receive investment and open to dialogue with investors.

A sufficiently high credit rating assigned by a specialized rating agency enhances the country's capabilities in any commercial or financial transaction. Regardless of whether a rating is used to attract investments, obtain loans, issue securities, sell products, or expand activities, a credit rating allows a local government, by demonstrating its creditworthiness, to enter into transactions on more favorable terms.
A credit rating is an effective means by which a local government can report its creditworthiness to investors who buy debt, banks, suppliers and customers entering into long-term contracts with the municipality. The rating is also an important part of the general program of maintaining relations with investors, contributing to an increase in the overall investment attractiveness.

A country's sovereign credit rating is a cumulative assessment of the current state and prospects of the corporate sector, that is, the state of national companies, the macroeconomic situation (inflation, the size and structure of foreign and domestic debt, the exchange rate) and a number of other macro indicators, as well as the stability of the political system.

Table 1 - Credit ratings

\begin{tabular}{|c|c|c|c|}
\hline Country & S\&P & Moody's & Fitch \\
\hline Kazakhstan & BBB- & Baa3 & BBB \\
\hline UAE & AA & Aa2 & AA \\
\hline Vietnam & BB & Ba3 & BB \\
\hline Saudi Arabia & A- & A1 & A+ \\
\hline Malaysia & A- & A3 & A- \\
\hline Russia & BBB- & Baa3 & BBB- \\
\hline $\begin{array}{l}\text { Note - compiled by authors on the basis of tradingeconomics. } \\
\text { com }\end{array}$
\end{tabular}

As we can see on the table above, the credit ratings of our country as well as of the Russian Federation are significantly lower comparing with other countries. Why this happens if all of these countries are similarly oil - producing? As was mentioned above, the credit rating is a cumulative indicator of the overall economic activity in the country. The described countries are focused not only on oil export, but also on tourism and other activities, which bring positive contribution to the country's economy.

As in our study, we find a relation between the oil price and stock market through the creditworthiness of the country; we need to pay attention on the capitalization of the following countries. Capitalization is a collection of all securities available in the market under study. This includes stocks and bills, bonds and other securities sold through stock exchanges. The existence of a certain security cannot be separated from its issuer. That is, the person who issued this action. Therefore, stocks 
and bonds traded on the market can be grouped by their issuers. Such a phenomenon as capitalization is an important characteristic of the stock market, allowing to find out the general positions of a certain state market or its industry. In this article, capitalization will be considered as a phenomenon of the stock market, when used as an indicator, allowing assessing the financial and economic level of not only the state, but also its specific economic sector (www.progress.org).

The study of the economic situation in a particular region or state can be based on several indicators. This may include indicators of gross domestic product (GDP), the ratio of exported and imported goods, the rate of national currency, the total number of existing facilities of heavy and medium industry, factories, factories, the volume of output and the development of the scope of services provided.

Table 2 - Stock market capitalization, billion USD, 2017

\begin{tabular}{|c|c|c|}
\hline Rank & Country & Capitalization, bln USD \\
\hline 17 & Russia & 623.42 \\
\hline 20 & Malaysia & 455.77 \\
\hline 21 & Saudi Arabia & 451.38 \\
\hline 27 & UAE & 239.39 \\
\hline 35 & Vietnam & 115.46 \\
\hline 46 & Kazakhstan & 45.56 \\
\hline
\end{tabular}

Moreover, concerning the oil price, in the fourth quarter of 2017, the average price for Brent oil was $\$ 61.5$ per barrel. Compared to the previous quarter, the price increased by $18 \%$, and compared to the corresponding quarter of 2016 - by more than $25 \%$. Oil price formation was influenced by a shortage of oil, accompanied by high demand and low supply from producer countries.

At the same time, the negative balance between production and oil consumption in comparison with the previous quarter of 2017 decreased and amounted to 0.32 million barrels per day. Oil consumption in the world after a slight slowdown began to gradually recover, mainly due to increased consumption in India, China and the United States. Main factor of the increase in oil consumption in India and the United States was the beginning of the heating season, in China; demand was due to the replenishment of strategic reserves and an increase in production capacity at the petrochemical plants of the country. Demand was constrained by reduced oil consumption in Russia, Japan and the EU (www. oilprice.com).

The pace of oil production in the world slowed down slightly. If in the third quarter oil production in the world increased by $1.3 \%$ in annual terms, in the fourth quarter of 2017 increase amounted to $0.03 \%$. In countries outside OPEC, oil production in the fourth quarter increased by $1.2 \%$ in annual terms, compared with $1.7 \%$ in the third quarter of 2017.

As for 2018, the average price for Brent crude for the third quarter was $\$ 75.2$ per barrel, which is $44.4 \%$ higher than in the third quarter of 2017 . One of the main fundamental reasons for the marked increase in oil prices is a reduction in global reserves due to the rapidly and steadily growing global demand for oil.

Global oil consumption in comparison with the corresponding quarter of the previous year increased by $1.5 \%$. The acceleration of global consumption was due to growing market fears for a further increase in oil prices, as well as expectations of a reduction in supply from Iran in connection with the sanctions by the United States. The situation in Venezuela continues to provide additional support for demand. Against the background of the influence of these factors, an increase in oil consumption was noted in China, India, and also in the USA, where increased demand further impacted industrial output growth and freight traffic (U.S. Energy Information Administration (EIA).

Since the beginning of 2019, participants of the OPEC + have reduced total oil production by 1.2 million barrels per day compared with the level of October 2018. This figure is comparable to the expected increase in the volume of world consumption in the current year. The current Brent oil costs have increased in price by about more than $30 \%$. Experts consider that there is a great possibility if the price goes higher. One of the main factors of this prejudice is aggregate demand. According to the statistics, the USA as one of the most developed countries, consumes more than $20 \%$ of crude oil (U.S. Energy Information Administration (EIA).

However, the oil market reacts not only to the dynamics of objective statistical indicators. We should also pay attention to the geopolitical risks. Nowadays, there is a great uncertainty in the world political situation; kind of the beginning of the era of international trade wars. 


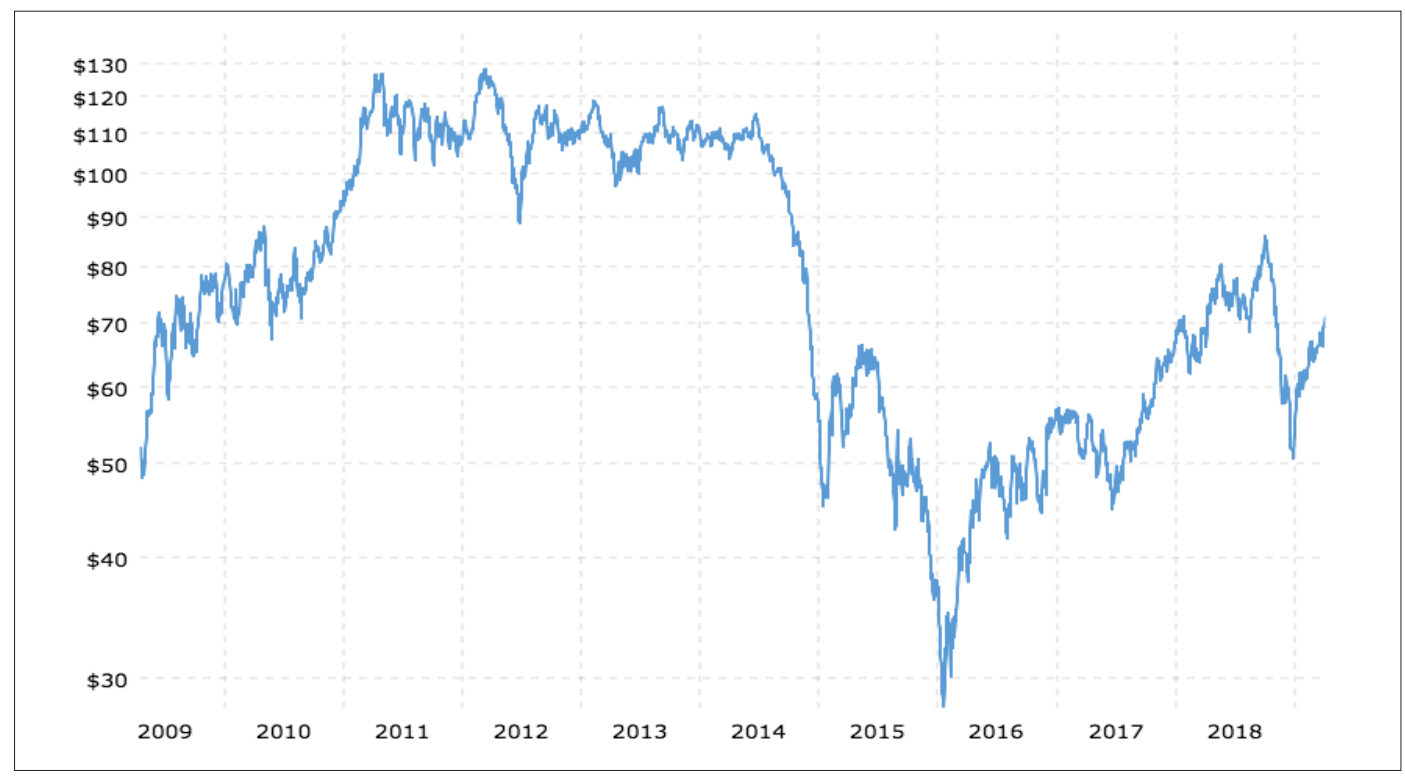

Figure 1 - Brent Oil Price (2009-2018)

Source: www.macrotrends.com

Table 3 - Crude Oil consumption by country

\begin{tabular}{|c|c|c|}
\hline & Country & $\begin{array}{l}\text { Consumption (Thousand } \\
\text { Barrels per Day) }\end{array}$ \\
\hline 1 & United States & $18,961.00$ \\
\hline 2 & China & $10,480.00$ \\
\hline 3 & Japan & $4,557.00$ \\
\hline 4 & India & $3,660.00$ \\
\hline 5 & Russian Federation & $3,493.00$ \\
\hline 6 & Brazil & $3,003.00$ \\
\hline 7 & Saudi Arabia & $2,961.00$ \\
\hline 8 & Germany & $2,435.00$ \\
\hline 9 & Canada & $2,374.00$ \\
\hline 10 & The Republic of Korea & $2,382.00$ \\
\hline
\end{tabular}

The US listed four companies and nine oil tankers associated with Venezuela on the sanctions list. Thirty-four vessels of the Venezuelan National Oil and Gas Company were also subject of sanctions. Venezuela's economy depends, first of all, on oil sales, and US sanctions force Venezuela not only to rush to look for new sources of income, but also to revise schemes for supplying the country with necessary goods and change technologies. Today, Russian oil enters the US refineries due to depletion of supplies to Venezuela. The United States is increasing its oil imports from Russia, as US refineries are demanding more oil now that Venezuelan oil supplies have dried up (Bloomberg NEF).

Overall, the presence of a large number of geopolitical threats to the global oil market is a significant factor in supporting oil costs.

\section{Conclusion}

An efficient stock market is its effect on entrepreneurs who consider both the profits generated in a new venture and the possibility of selling the venture to the public. In inefficient stock markets the public offering is less feasible due to high transaction costs or the uncertainty of getting a fair price. Thus, inefficient stock markets may reduce the incentive to enter new ventures, reducing overall long- term productivity of the economy. An efficient stock market reduces the transaction costs of trading and thereby opens the way for an optimal ownership structure. Certain individuals possess the entrepreneurial spirit for "new start" ventures and should be involved in the innovation phase of a firm's development. As the firm matures, they often transfer ownership to investors that specialize in running mature firms. The entrepreneurs can then move on to another fledgling company. This is the idea of optimal ownership. Clearly, transferring the ownership of such assets would be very difficult without stock markets.

The stock market contributes to economic growth in various ways. First, without efficient capital 
markets, investors have limited opportunities to diversify their portfolios and can avoid equity stakes due to risk. Consequently, corporations can hardly raise their capital. Creating stock markets allows individuals to diversify company-specific risks, which makes investments in firms more attractive (Nazlioglu et al., 2012). To attract investment capital in countries with poorly functioning capital markets, corporations can opt for lower-value, lowrisk projects for inefficient diversification. These projects may not even fall under the purview of the corporation. They serve to diversify, since capital markets do not provide funds for investors in this country for effective diversification. Consequently, the stock market plays a key role in economic growth (Barro, 1990).
Second, country's creditworthiness is highly important for foreign investors whether to decide give the loan or not. The country's creditworthiness is mainly depended on the internal macroeconomic factors as GDP, real exchange rate, inflation and etc. The country's creditworthiness is a kind of reliability indicator that reflects the borrower's ability to get a loan and return it on time. If the state's rating drops, the investment attractiveness of its market automatically decreases.

Overall, we can see the clear image that the creditworthiness of the leading oil-exporting countries is different. We notice that countries as Kazakhstan and Russia, which highly depend only on one oil export are more vulnerable in comparison with other economies, which diversify their internal economic conditions.

\section{References}

1 Bernanke B. (2016) The relationship between stocks and oil prices, https://www.brookings.edu/blog/ben-bernanke/2016/02/19/the-relationship-between-stocks-and-oil-prices/

2 Bloomberg NEF (2019) Available at: https://about.bnef.com/

3 Country Economy (2019) Sovereign Ratings List, Available at: https://countryeconomy.com/ratings

4 Harms P., Rauber M. (2004) Foreign aid and developing countries' creditworthiness. Working Paper, https://www.econstor. eu/handle/10419/128026

5 Index Mundi - Country Facts (2019) Economy - Overview, https://www.indexmundi.com/

6 Kharas H. (1984) The Long-Run Creditworthiness of Developing Countries: Theory and Practice. The Quarterly Journal of Economics, vol. 99, no. 3, pp. 415-439.

7 Nadeem Ul Haque, Manmohan S. Kumar, Nelson Mark, Donald J. Mathieson (1996) The Economic Content of Indicators of Developing Country Creditworthiness. Staff Papers - International Monetary Fund, vol. 43(4), p. 688, doi: 10.2307/3867366

8 Nazlioglu S., Soytas U. (2012) Oil price, agricultural commodity prices, and the dollar: A panel cointegration and causality analysis. Energy Economics, vol. 34(4), pp. 1098-1104, doi:10.1016/j.eneco.2011.09.008

9 Oil price (2019) Source for Oil and Energy News, https://oilprice.com/oil-price-charts

10 Rowland P. (2004) Determinants of Spread, Credit Ratings and Creditworthiness for Emerging Market Sovereign Debt: A Follow-Up Study Using Pooled Data Analysis. Banco de la República.

11 Progress insight that matters (2015) Economic Capitalization: Fred Foldvary, Ph.D. Economist, https://www.progress.org/ articles/economic-capitalization

12 Gelos R.G., Sahay R., Sandleris G. (2011) Sovereign borrowing by developing countries: What determines market access? Journal of International Economics, vol. 83, issue 2, pp. 243-254.

13 Barro R.J. (1990) The Stock Market and Investment. The Review of Financial Studies, vol. 3, issue 1, pp. 115-131, https:// doi.org/10.1093/rfs/3.1.115

14 The Global Economy (2019) Political stability - Country rankings, https:/www.theglobaleconomy.com/rankings/wb_political stability/

15 Trading Economics (2019) Trading Economics: Commodities, https://radingeconomics.com/commodities

16 US. Energy Information Administration (2019) Markets and Finance, https://www.eia.gov/

17 World Bank (2019) Projects \& Operations, http://projects.worldbank.org/country?lang=en\&page=

18 Trade Map (2018) Trade statistics for international business development, Monthly, quarterly and yearly trade data. Import \& export values, volumes, growth rates, market shares, etc., https://www.trademap.org/stDataSources 